\title{
A NEW SPECIES OF HYALOTIELLA
}

\author{
By V. Agnihothrudu, F.A.Sc.* and Padmabhai LUke $\ddagger$
}

Received September 22, 1969

IN the course of investigations on the fungal flora of some important trees in Bangalore, an interesting hyphomycetous fungus was isolated from the bark of Tamarindus indica $\mathrm{L}$. The fungus was found to grow well on potato dextrose medium and has been assigned to the recently described genus Hyalotiella Papendorf (1967).

In the incubation chamber the pycnidia appeared as minute irregular dark brown discrete dots producing abundant spores. In culture the isolate produced creamy-white to dirty white floccose mycelium. The pycnidia are produced in culture in plenty and the sporulation was seen in 8-10 days at laboratory ambient temperatures of $20-28^{\circ} \mathrm{C}$.

Papendorf (loc. cit.) described the monotypic genus Hyalotiella during his investigations of the soil microflora of Acacia karro community in Potchefstroom ncar Johannesburg in South Africa. The type species was named H.transvalensis. The fungus occurring in Bangalore differs from the type species of Hyalotiella and hence a new species is proposed here.

Hyalotiella subramaniani Agnihothrudu and Padmabhai Luke, sp. nov.

Colonies on potato dextrose agar fast-growing white foccose, hyphae, hyaline, smooth, branched, septate upto $8 \mu$ in diameter, the repent mycelium subhyaline to olivaceous and guttulate. Fruit bodies immersed in the medium globose, at times prominently lobate measuring upto $1,000 \mu$, dark brown to black without ostiole, conidiophores subhyaline, simple, cylindrical, obclavate, or pyriform $8-25 \times 4-8 \mu$ bcaring conidia singly and terminally, conidia cylindrical, generally slightly curved, rarely straight, thin and smooth-walled, mostly 3-septate, very rarely 4-septate, $18-36(-47) \times 3-5 \cdot 5$ $(-7 \cdot 2) \mu$. The basal and the terminal cells hyaline, the intermediary cells subhyaline, the apical cell narrowing to a conical pointed end crested with $2-3(-4)$ setae, generally one of the setac is not branched, the other setae are branched into 2,3 or 4 , the branches being widely divergent and filiform.

\footnotetext{
Technical Adviser, Fertilizers and Pesticides Division, Rallis India Ltd., 6-A, Cunningham Road, Bangalore-1 B.
}

¥ Lecturer in Botany, Bangalore University, Bangalore. 
The setae measure $28-43(-54) \mu$, no sign of a pedicel was observed although traces of supporting cell were noticed in some cases.

Isolated from the bark of tamarind (Tamarindus indica L.), Bangalore, deposited in Commonwealth Mycological Institute, U.K. and C.B.S., Holland, type isolated by Dr. Padmabhai Luke, dated 15-11-1968 deposited in the Mycological Collections, Bangalore University, under No. 24.

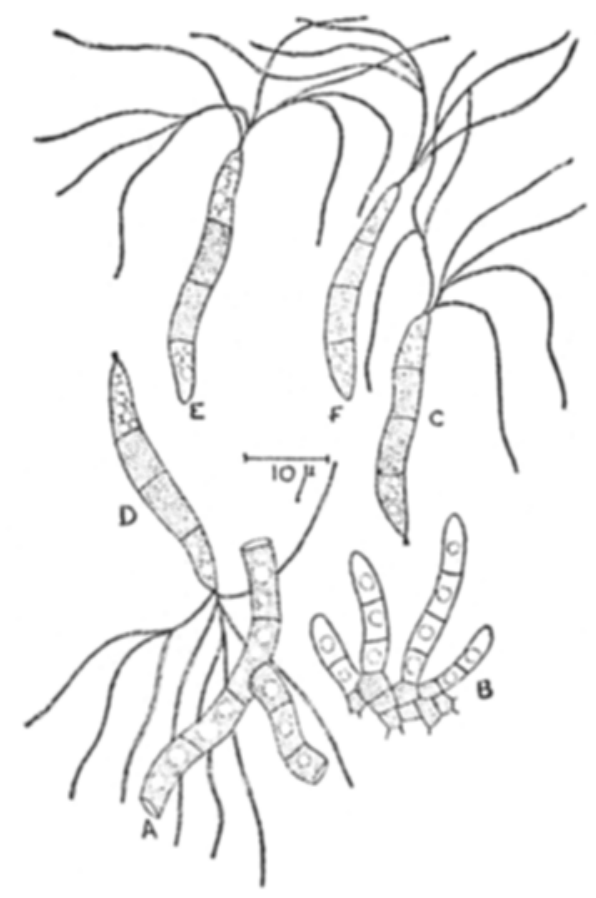

TExr-Fig. 1. Hyalotiella subramaniani Agnihothrudu and Padmabhai Luke. A, Substrate mycelium; B, Conidiophores; C, D, E, F, Pycnidiospores.

\section{Hyalotiella subramaniani Agnihothrudu et Padmabhai Lake sp. nov.}

Coloniae abundanter producta in mediis plurimis in laboratorio, alba, floccosae. Hyphae hyalinae, ramosae, septatae usque ad $8 u$ in diam., mycelium repens subhyalinum vel olivaceum et guttulatum. Pycnidia globosae quandoque prominenter lobatae, brunneae vel nigrae, non-ostiolotae usque ad $1,000 \mu$. Conidiophora subhyalina, simplicia, cylindrica, obclavata vel pyriformia, $8-25 \times 4-8 \mu$. Conidia ferentes singula et terminalia, saepae paulo curvata, raro recta, parietibus tenuibus, 3-septata, rarissime 4-septata, $18-36(-47) \times 3-5 \cdot 5(-7 \cdot 2) \mu$. Cellulae basalis et terminalis hyalinae, intermediae vero subhyalinae, cellula apicalis in finem acutum et conicum angustata et setis 2-3(-4) cristata, quae sunt 2-3 sacpac 
trifurcatis ramis devergentibus et filiformibus, alter setae simplicibus $28-43$ (-54) $\mu$. Pedicelli non-observati, etsi vestigia cellulae supportatis in aliquibus casibus visa sunt.

Typus urbe Bangalorense ex corlice Tamarindi indicae isolatis a Padmabhai Luke die 15th nov. 1968 et positus herbarium Mycologicae Universitatis Bangalorensis subnumero 24.

Hyalotiella differs from Hyalotia, which was described by Guba (1961) in the colour of conidia. Those of Hyalotia being subhyaline in contrast to the dark conidia of Pestalotia. The feature which distinguishes Hyalotiella is the absence of the pedicel cell on the basal cell of the conidia, which is characteristically present both in Pestalotia as well as in Hyalotia. The species occurring in Bangalore is different from Hyalotiella transvalensis Papendorf in having larger conidia with slightly coloured intermediary cells and in having more number of filiform branched setae arising from the top of the apical cell in the form of a trident. In H. transwlensis the terminal cell of the conidium is more or less conical and terminates in a beak-like extension on which 3 to 4 setae are borne. The fungus is named after Prof. C. V. Subramanian of the Advanced Research Centre for Mycology, Madras University, whose contributions to the study of hyphomycetes are very well known.

\section{ACKNOWLEDGEMENTS}

The authors are grateful to the General Manager, Fertilizers and Pesticides Division, Rallis India Limited, and Professor of Botany, Bangalore University, for permission to publish this article and facilitating this work. They are thankful to Dr. M. B. Ellis of the Commonwealth Mycological Institute, Dr. R. L. Steyaert of Brussels and Prof. Dr. J. A. von Arx of Central Bureau yoor Schimmelcultures, Holland, for their criticism and to Rev. Fr. Cecil J. Saldanha of St. Joseph's College, Bangalore, for rendering the Latin diagnosis of the specirs.

\section{REFERENCES}

Guba, E. F.

Papendorf, M. C.
. Monograph of Monochaetia and Pestalotia, Harvard University Press, 1961, pp. vi +342 .

.. "Two new genera of soil fungi from South Africa," Trans. Brit. ntycol. Soc., 1967, 50(1), 69-72. 